\title{
Schoenoplectus $\times$ flevensis (S. lacustris $\times$ S. tabernaemontani, Cyperaceae) in Britain
}

\author{
Richard V. Lansdown ${ }^{1 *}$; Fred Rumsey ${ }^{2}$ \\ ${ }^{1}$ Associate Researcher, Natural History Museum, London; ${ }^{2}$ Senior Curator, Natural \\ History Museum, London
}

*Corresponding author: Richard V. Lansdown: rvlansdown@gmail.com

This pdf constitutes the Version of Record published on $31^{\text {st }}$ August 2020

\begin{abstract}
Intermediates between Schoenoplectus lacustris and S. tabernaemontani have been recognised at least since the late $19^{\text {th }}$ century and for much of that time, there has been speculation that such intermediates may involve hybridisation. In 2017 the hybrid status of a population growing in the South-Forty-foot Drain in Lincolnshire was confirmed using molecular tools. This article presents information on the hybrid, both from the Lincolnshire population and from the literature, as well as providing an indication of how hybrid populations might be recognised. The binomial Schoenoplectus $\times$ flevensis (D.Bakker) Lansdown \& Rumsey is proposed for the hybrid.
\end{abstract}

Keywords: hybridisation; molecular identification; Lincolnshire

\section{Introduction}

Many authors have recognised the occurrence of intermediates between Schoenoplectus lacustris (L.) Palla and S. tabernaemontani (C.C.Gmel.) Palla (e.g. Otzen, 1962; Davis, 1968; Kukkonen, 1996; Jermy et al., 2007) and the frequent occurrence of such intermediates is likely to have contributed to uncertainty about the taxonomic status of these two taxa (e.g. Bakker, 1954). One element of these intermediates was described as Scirpus lacustris subspecies flevensis (Bakker,1954). At least since the late $18^{\text {th }}$ century some authors have considered these intermediates to represent hybrids (e.g. Buchenau, 1877; Focke, 1881; Brügger, 1882; Lousley, 1931; Davis, 1968; Easy, 1990), but to-date this has not been confirmed.

In 2010 parts of the South Forty-foot Drain, between Boston and Guthram Gowt, near Spalding, South Lincolnshire (v.c.53), were surveyed as a contribution to works to inform the proposed Fen Waterways Link project (Lansdown, 2010). The South Forty-foot Drain supports extensive populations of both Schoenoplectus lacustris and S. tabernaemontani, occasionally in mixed stands. During surveys, a number of stands of Schoenoplectus were encountered which were very tall, resembling $S$. lacustris but grey-green or glaucous, resembling $S$. tabernaemontani and which appeared likely to represent hybrids (Fig. 1). Inclusion of such plants in work funded by the Natural England Species Recovery Programme to investigate the identity of Schoenoplectus populations in the UK (Lansdown, 2017; Saubin et al., 
2018) provided molecular data that strongly supported their identification as hybrids between $S$. lacustris and $S$. tabernaemontani. This article presents a formal description of the hybrid and considers evidence for its occurrence elsewhere in the United Kingdom, as well as in other regions.

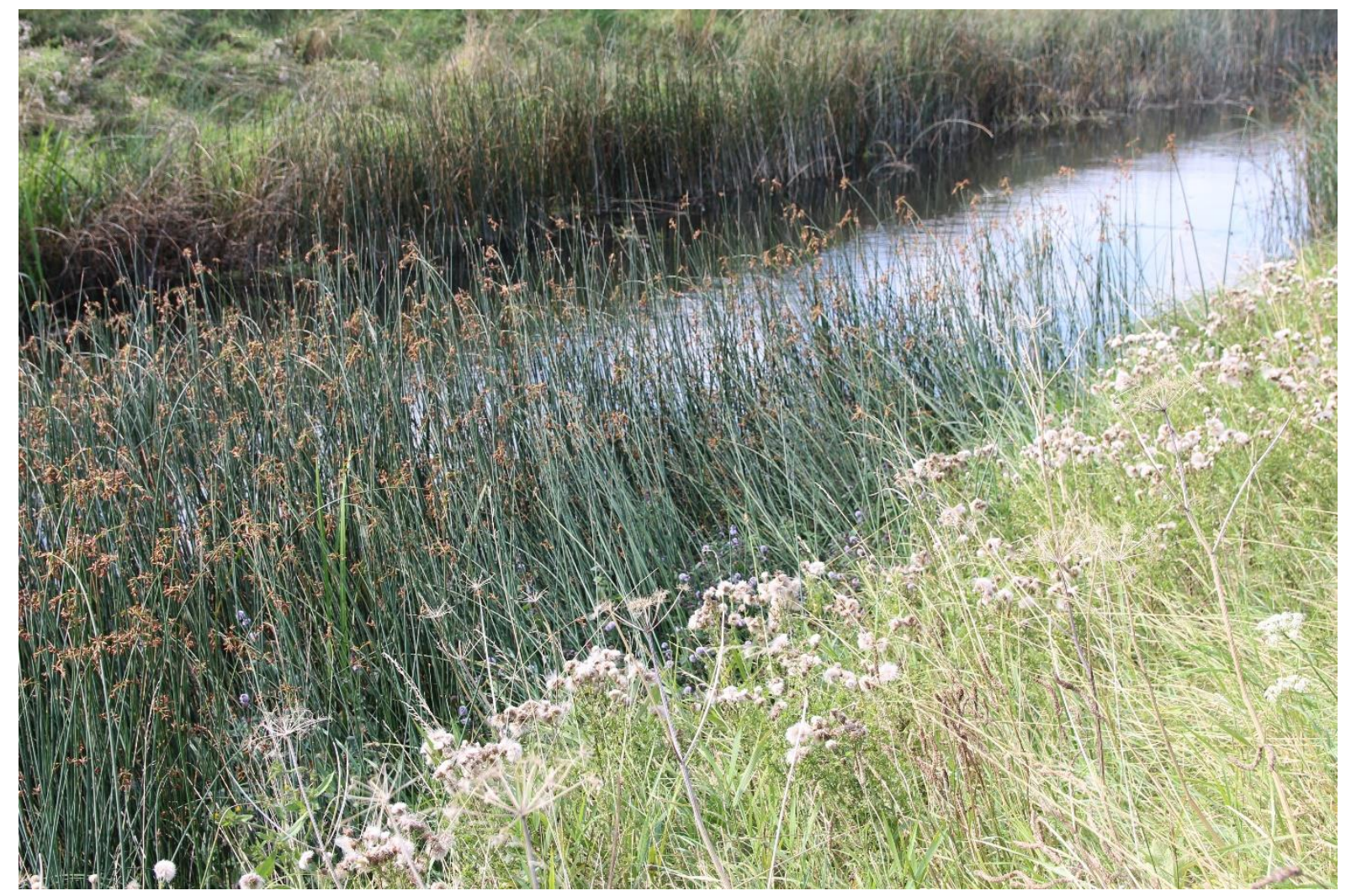

Figure 1. Extensive stands of Schoenoplectus $\times$ flevensis on the South Forty-Foot Drain, Lincolnshire

\section{Taxonomic treatment}

Schoenoplectus $\times$ flevensis (D.Bakker) Lansdown \& Rumsey comb. \& stat. nov.

Type: Scirpus lacustris subsp. flevensis D. Bakker (1954). Type: Ketelveld, bij de uitmonding van de Yssel (Flevoland), ondiep uoet water, Netherlands, 1 July 1953, Bakker, D. 1153 (L 0442940).

Voucher: South Forty-foot Drain, approximately $1.5 \mathrm{~km}$ north of Guthram Gowt Lincolnshire, TF1689424115, $13^{\text {th }}$ August 2017, R.V. Lansdown S.n. (BM).

- Scirpus $\times$ buchenaui Cif. \& Giacom., nom. nud.

- Schoenoplectus $\times$ buchenaui (Cif. \& Giacom.) Rothm. nom. nud.

\section{Description}

Perennial, rhizomatous forming extensive stands. Stems (125-)142-194 cm high $\times$ (0.7-)0.6-1.2 cm diameter, terete, glaucous. Leaves of terrestrial plants reduced to sheaths, pale brown, free part of sheath 1.4-120 cm, leaves of plants growing in water not seen. Inflorescence branched, with 16-55 spikelets, on peduncles 0-47(51) $\mathrm{mm}$, secondary peduncles $0-21(-23) \mathrm{mm}$ bearing $1-5$ spikes, Inflorescence 
lowest bract 3.2-4.9(-5) $\mathrm{mm}$, brown and dry. Spikes 7.1-14.8mm, ovate to ovatelanceolate, 13-28 flowered. Glumes (Fig. 2) 3.6-4.3 mm, ovate; smooth, with glabrous margins, denticulate to the apex, which is not emarginate; pale brown, scarious to the base, 1-nerved, usually with a green central band and narrow scarious margins, sometimes absent. Filaments $2.8-3.8 \mathrm{mmm}$, anthers $1.2-1.8 \mathrm{~mm}$, yellow. Styles 2.4-2.9 mm, 2-3-fid. Achenes 2.2-2.8 mm not including beak 0.1-0.3 $\mathrm{mm}$, obovate, broadly trigonous, with small irregularly distributed wrinkles visible under magnification, yellowish when immature, dark brown to blackish when mature, shining; perianth bristles 5, 2.1-2.8 $\mathrm{mm}$.
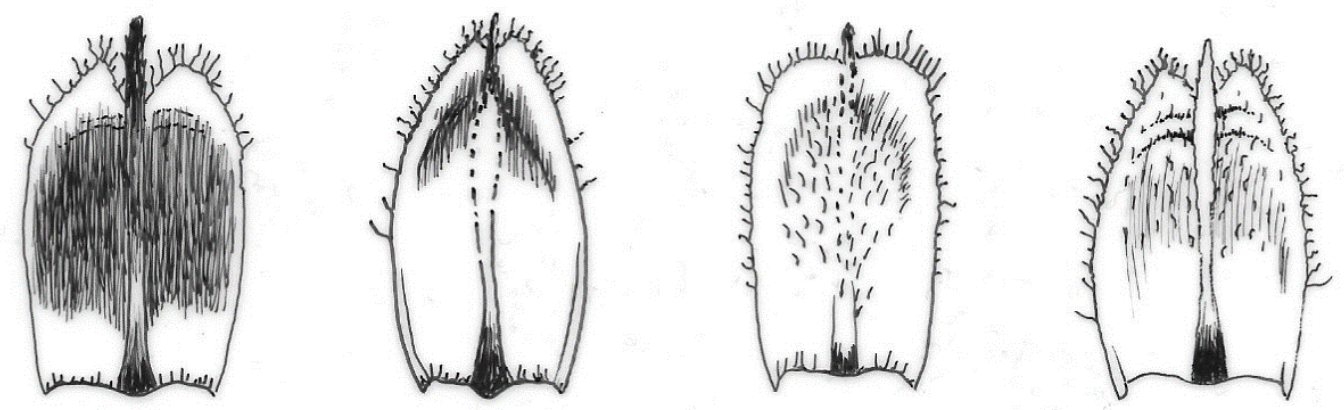

Figure 2. Illustrations of the glumes of (left to right) Schoenoplectus lacustris, $S$. $\times$ flevensis, S. tabernaemontani and S. hippolyti

S. lacustris, Little Avon River, Berkeley, West Gloucs. v.c. 34, ST67831.99049, $16^{\text {th }}$ May 2020, R.V. Lansdown.

S. tabernaemontani, small pond off the Stroudwater Canal, Queen Elizabeth II

Playing Field, West Gloucs., SOO83220.04710, $16^{\text {th }}$ May 2020, R.V. Lansdown.

S. hippolyti, swamp near Kurchenko Village, Astrakhan Oblast, $40^{\circ} 12^{\prime} 11^{\prime \prime} \mathrm{N}, 47^{\circ} 30^{\prime}$

$17^{\prime \prime} \mathrm{E}, 7^{\text {th }}$ June 2012, A. Mesterhazy \& D. Pitko S.n. (herb. A. Mesterhazy).

\section{Identification}

The populations of $S . \times$ flevensis on the South Forty-Foot Drain are most readily recognised by their stem size being more typical of $S$. lacustris but (usually) being glaucous in colour, combined with their lax and open panicles due to the length of the secondary branches (Fig. 3) (see also Table 1).

Data from the literature (Buchenau, 1877; Focke, 1881; Bakker, 1954; Lousley, 1931) suggest that hybrids may have stems green, $\leq 2.75 \mathrm{~m}$ high and $<6$ $\mathrm{cm}$ diameter, glumes smooth (glabrous), reddish-brown and anthers not bearded. Bakker's (1954) circumscription of his subsp. flevensis (Table 2) provides a number of other characters which may be useful in recognition of the hybrid.

\section{Distribution}

S. $\times$ flevensis has only been confirmed from the margins of the southern end of the South Forty-foot Drain in Lincolnshire. Plants intermediate between the parents and likely to involve this hybrid have also been reported from Denmark (Lousley, 1931; Bakker, 1954); France (Grenier and Godron, 1855-56); Bremen (Focke, 1881; 
Buchenau, 1877), Germany (Brügger, 1882; Lousley, 1931, Bakker, 1954); the River Medway near Newhythe; Wytham ditches (Lousley, 1931), Whittlesford Gravel Pit (Easy, 1990), the old chalk pit at Barrington, Cambridge and the country park beside Addenbrooke's Hospital, Cambridge (A. Leslie pers. comm.), Great Britain (Jermy et al., 2007); Lago di Chiusi, Italy (Pignotti, 2003); Zwarte Water and a pool along Overijsselse Vecht near Dalfsen, brackish tidal estuaries in the south-west, the IJsselmeer, Koelood, Oude Mass and Kamperisland (Bakker, 1954), Netherlands (Lousley, 1931, Otzen, 1962); and Kartal to Maltepe, Istanbul, Turkey (Davis, 1968).

Table 1. Identification characters of Schoenoplectus $\times$ flevensis

\begin{tabular}{|l|l|l|l|}
\hline & S. lacustris & S. $\times$ flevensis & S. tabernaemontani \\
\hline Stem & $\begin{array}{l}\text { Robust, green, } \\
<350(-400) \times \\
0.5-1.5 \mathrm{~cm}\end{array}$ & $\begin{array}{l}\text { Robust, } \\
\text { glaucous 125- } \\
200^{1} \times(0-7) 0.6- \\
1.2 \mathrm{~cm}\end{array}$ & $\begin{array}{l}\text { Slender, glaucous } \\
<150(-270) \times 3-9 \mathrm{~cm}\end{array}$ \\
\hline $\begin{array}{l}\text { Secondary panicle } \\
\text { branches }\end{array}$ & $<1.5 \mathrm{~cm}$ & $<2.3 \mathrm{~cm}$ & $<1.3 \mathrm{~cm}$ \\
\hline Spikelets & $6-15 \mathrm{~mm}$ & $7.1-14.8 \mathrm{~mm}$ & $4-10 \mathrm{~mm}$ \\
\hline Glumes & $\begin{array}{l}2.5-4 \mathrm{~mm}, \\
\text { without hooked } \\
\text { barbs }\end{array}$ & $\begin{array}{l}3.6-4.3 \mathrm{~mm}, \\
\text { without hooked } \\
\text { barbs }\end{array}$ & $\begin{array}{l}2.5-3.7 \mathrm{~mm}, \text { with } \\
\text { hooked barbs }\end{array}$ \\
\hline Anthers & $\begin{array}{l}2-2.5 \mathrm{~mm}, \text { apex } \\
\text { rounded }\end{array}$ & $\begin{array}{l}1.2-1.3 \mathrm{~mm}, \\
\text { apex variable }\end{array}$ & $\begin{array}{l}2-2.5 \mathrm{~mm} \text {, apex } \\
\text { tapered }\end{array}$ \\
\hline Stigmas & $\begin{array}{l}2-) 3 \\
2-3\end{array}$ & $2(-3)$ \\
\hline $\begin{array}{l}\text { Achenes } \\
\text { (excluding beak) }\end{array}$ & $\begin{array}{l}2.5-3 \mathrm{~mm}, \\
\text { trigonous }\end{array}$ & $2.2-2.8 \mathrm{~mm}$ & $\begin{array}{l}2-2.5 \mathrm{~mm}, \\
\text { compressed }\end{array}$ \\
\hline
\end{tabular}

${ }^{1}$ Scirpus lacustris subsp. glaucus f. maior is described as reaching $<2.75 \mathrm{~m}$ in height

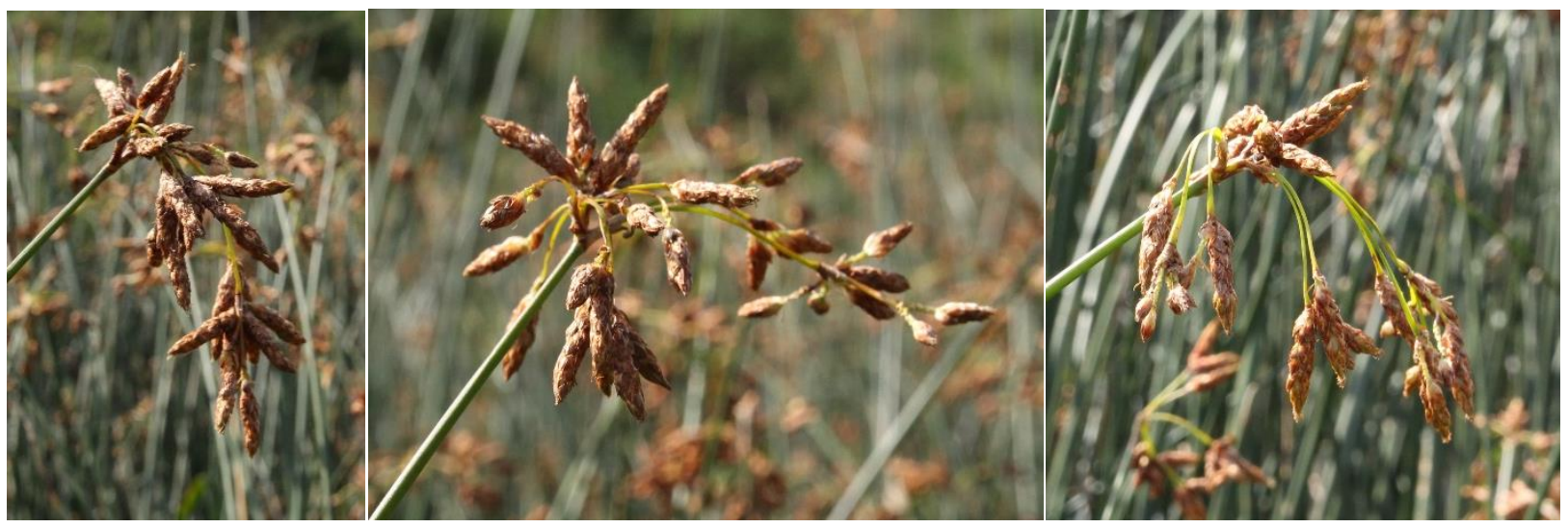

Figure 3. A range of flowering heads of Schoenoplectus $\times$ flevensis on the South Forty-Foot Drain, Lincolnshire 


\section{Habitat and ecology}

There is very little information in the literature on the habitat in which $S . \times$ flevensis occurs. As might be expected from the habitat preferences of the parents, most accounts are from coastal areas or the tidal reaches of large rivers, such as the former mouth of the R. IJssel which was a freshwater estuary, with occasional seawater inflow due to tide and storms, and the Oude Maas (Bakker, 1954), as well as the R. Medway (Lousley, 1931). The IJsselmeer is an interesting situation, where $S . \times$ flevensis occurred around the mouth of the River IJssel but after this was enclosed to form the Ijsselmeer, $S . \times$ flevensis would have disappeared, as it could not compete with $S$. lacustris, were it not continually replanted, at least until the 1950s (Bakker, 1954). The plant was propagated and preserved as it was used for the manufacture of rush-bottomed chairs for which the mechanical properties of its stems best suited it. $S$. $\times$ flevensis is no longer cultivated in the area, but has been recorded there at least until the late 1990s (A. Corporaal pers. comm. to J. Bruinsma).

The South Forty-foot Drain presents another interesting situation. The drain runs south-north along the former confluence of spring-fed streams and freshwater marshes arising from the Lincolnshire Wolds and the inland limits of coastal marshes (Lansdown, 2017). Drainage of the marshes and conversion of the land to arable was achieved by the creation of a network of minor ditches and larger drains, together with canalisation of rivers such as the River Glen. It is likely that the extensive populations of $S$. tabernaemontani are a relic of populations growing in the former brackish marshes, while $S$. lacustris has probably expanded its range along the freshwater ditch system. It is also likely that $S$. $\times$ flevensis will have arisen in situ in this area. The South Forty-foot Drain supports a diverse aquatic flora, in part derived from the rich wetland flora of the ditch network, the River Glen and remnant marshes such as at Baston Fen Nature Reserve (Lansdown, 2017). The southern section of the South Forty-foot Drain, north of Guthram Gowt supports more than 25 aquatic plant species, ranging from nitrophiles such as Ceratophyllum demersum, Lemna gibba and Stuckenia pectinata, as well as filamentous algae such as Cladophora glomerata, Ulva flexuosa and Vaucheria sp(p). to species typical of calcareous fens such as Myriophyllum verticillatum, Potamogeton trichoides and Ranunculus circinatus. The area from which $S . \times$ flevensis was confirmed was characterised by Berula erecta, Lemna gibba, L. trisulca, Sagittaria sagittifolia and Sparganium erectum in the water, with Carex acutiformis and Schoenoplectus lacustris on the margin and extensive stands of $S . \times$ flevensis along the margins and extending into water to a depth of about $1 \mathrm{~m}$.

\section{Discussion}

The taxonomic status of Schoenoplectus lacustris and S. tabernaemontani has long been disputed, with different authors treating them as subspecies of $S$. lacustris (e.g. Bakker, 1954; Sell and Murrell, 1996) or as different species (e.g. Otzen, 1962; Stace, 2019). One of the reasons for this inconsistency has been the widespread occurrence of plants intermediate between the concepts of the species, such that Grenier and Godron (1855-56) stated that "Aucun des caractères par lesquels on a voulu distinguer [S. tabernaemontani] du S. lacustris n'est constant" [none of the characters by which one might distinguish $S$. tabernaemontani from $S$. lacustris is constant]. However, cytological (Otzen, 1962) and molecular analysis (Saubin et al., 
2018) have shown that $S$. tabernaemontani is more closely related to $S$. triqueter than $S$. lacustris and there is therefore no justification for their treatment as elements of the same species.

S. lacustris and S. tabernaemontani are usually distinguished by the following characters (Table 1): the stem height is greater in S. lacustris and the stem is green, as opposed to glaucous, the glumes of $S$. tabernaemontani have red barbs which are lacking in S. lacustris, S. lacustris typically has three stigmas and trigonous achenes whereas $S$. tabernaemontani usually has two stigmas and the achenes are planoconvex.

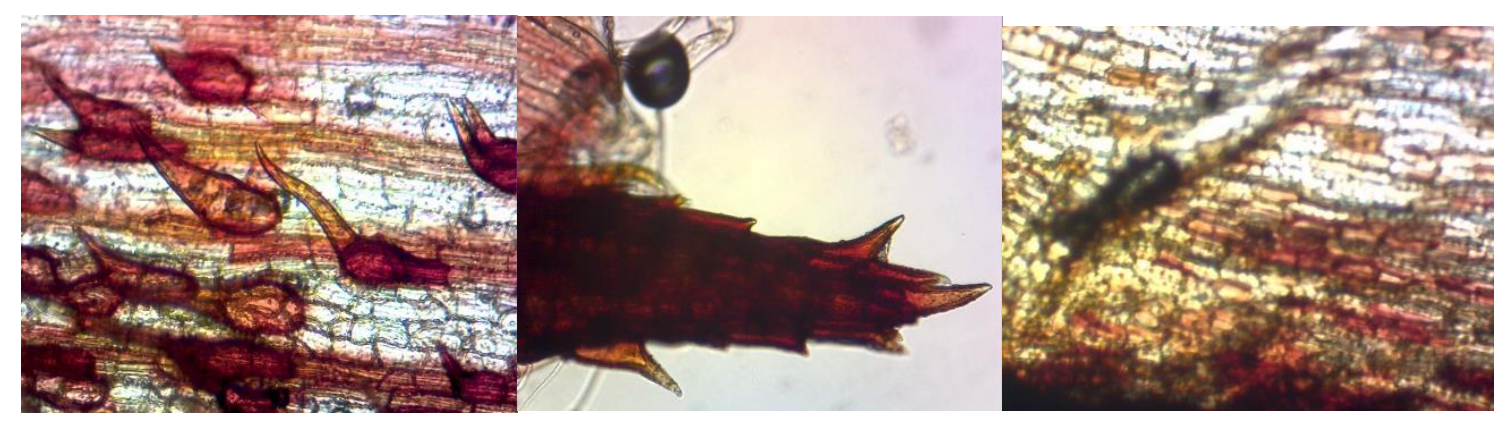

Figure 4. Structures on the glumes of Schoenoplectus species: a (left) - barbs on the glume of $S$. tabernaemontani; b (centre) - teeth; and c (right) - thickenings on the glume of $\boldsymbol{S}$. lacustris (specimens as for Fig. 2)

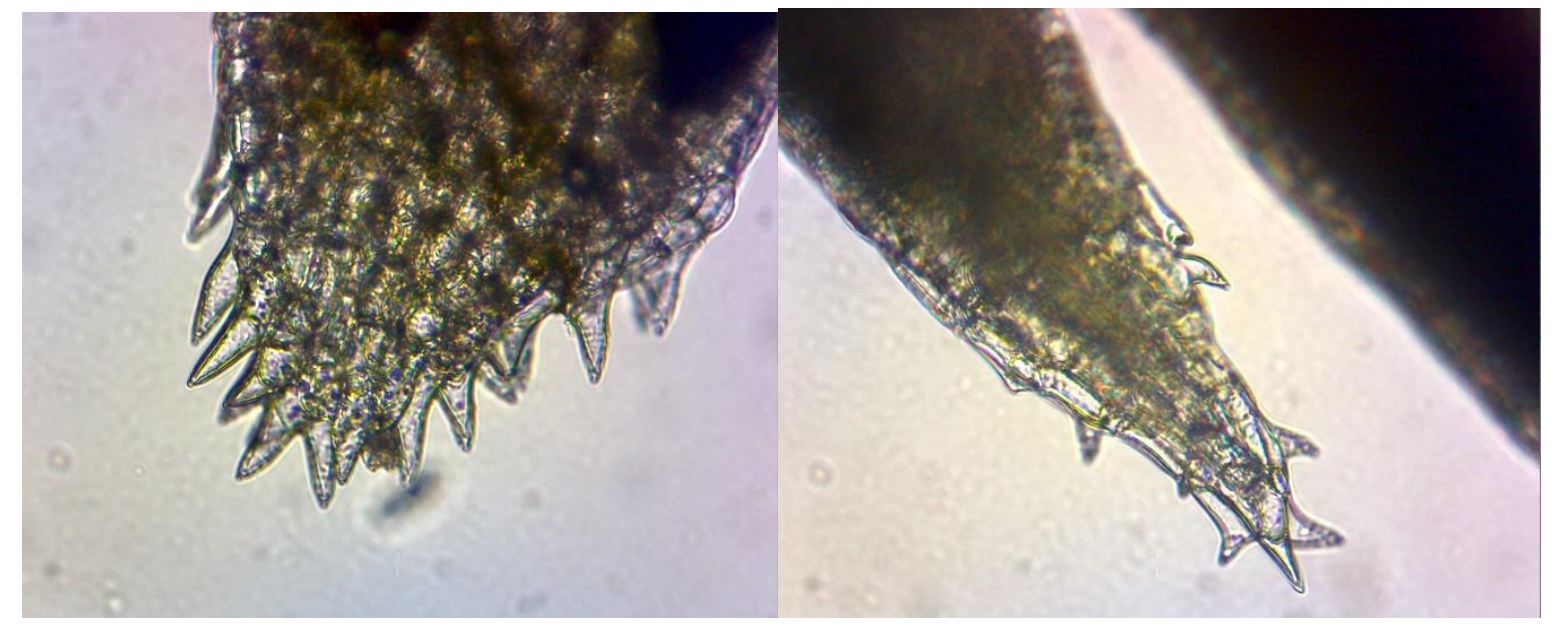

Figure 5 Apices of anthers of (left) S. lacustris and (right) S. tabernaemontani (specimens as for Fig. 2)

The structures on the glumes of $S$. tabernaemontani and their importance in distinguishing this species from $S$. lacustris have been referred to by a number of names, including papillae (Davis, 1968; Rose, 1989; Sell and Murrell, 1996; Jermy et al., 2007; Stace, 2019), reddish resinous spots (Lun-Kai et al., 2010), reddish barbs (Kukonnen, 1996) or reddish-brown, basally inflated barbs (Pignotti, 2003). The reason for these differences is likely to be that there are two or three different structures on the glumes of one or all of $S$. lacustris, S. tabernaemontani and $S$. $\times$ flevensis. S. tabernaemontani bears large numbers of barbs (Fig. 4a) with the base expanded and the pointed apex angled upward on the abaxial face of the glumes. 
On the excurrent apex of the midrib, both $S$. lacustris and $S$. tabernaemontani may have varying numbers of teeth which appear similar to the barbs but taper gradually from the base (Fig. 4b). Finally, all three taxa have varying numbers and extent of red to blackish thickenings (Fig. 4c) extending along the midrib from the apex half to two-thirds of the way to the base, generally along the sides but in some cases scattered over the midrib. The diagnostic character for S. tabernaemontani is therefore the barbs and not other structures.

Bakker (1954) and others also refer to the presence of absence of a "beard" on the "connectiva" on the anthers of $S$. lacustris but not on those of $S$. tabernaemontani. However, as can be seen from the photograph (Fig. 5), both species have similar structures (clearly visible as teeth, rather than a beard at high magnification), but the apex of the anther of $S$. lacustris is broad and rounded with a fringe of teeth, whereas that of $S$. tabernaemontani is narrow and tapered to the apex with teeth all around.

Plants intermediate between $S$. lacustris and $S$. tabernaemontani have been widely reported (see above), but to-date "no proof of hybridisation has been given" (Jermy et al., 2007). Unfortunately, it is difficult to know how to treat most of the published data, except perhaps for data presented by Lousley (1931) as different authors have applied different and inconsistent concepts of the morphological limits of $S$. lacustris and $S$. tabernaemontani.

There has been speculation that Schoenoplectus hippolyti (V.I.Krecz.) V.I. Krecz. ex Grossh. actually represents hybrids between $S$. lacustris and $S$. tabernaemontani and the type of $S$. hippolyti was considered to agree with Bakker's (1954) concept of Scirpus lacustris subsp. flevensis (A. Corporaal pers. comm. to J. Bruinsma). Material of $S$. hippolyti from the Astrakhan region of southern Russia was compared with $S . \times$ flevensis from the south Forty-Foot Drain. There is overlap in many characters, e.g. Stem glaucous-green, achenes 2-2.5 mm, stigmas 2-3. However, the glumes and spikelets of $S$. hippolyti are shorter than those of $S$. $\times$ flevensis (3-4 $\mathrm{mm}$ and 6.8-8 $\mathrm{mm}$ respectively) and have barbs resembling those of S. tabernaemontani (Fig. 2). The spikelets of $S$. $\times$ flevensis are also long, cylindrical and tapering toward the apex (Figure 6), while those of $S$. hippolyti are short and ovoid. In addition, most of the anthers of the specimen of $S$. hippolyti examined were fully formed and releasing pollen, whereas those of $S . \times$ flevensis were mainly withered and empty. $S . \times$ flevensis and $S$. hippolyti are clearly different.

Treating S. lacustris and S. tabernaemontani as subspecies of Scirpus lacustris, Bakker (1954) described S. lacustris subspecies flevensis, named for Lake Flevo which formerly occupied the area from which this taxon was collected. Lake Flevo was originally a freshwater lake before becoming linked to the sea in the Middle Ages (and named the Zuidersee), then enclosed in 1932 and renamed the Ijsselmeer (J. Bruinsma pers. comm.). He applied this name to what he described as stable populations intermediate between $S$. lacustris and S. tabernaemontani, occurring in the Yssellake but he did not include other populations intermediate between $S$. lacustris and S. tabernaemontani from the Netherlands and Germany, which he considered to fall within the natural morphological variation of either $S$. lacustris or S. tabernaemontani. Bakker (1954) did note "it is still possible that the ssp. flevensis should in fact be a hybrid" and "it is thought that the ssp. flevensis originated from crossings between ssp. lacustris and ssp. glaucus (= tabernaemontani) followed by back-crossings with the parents which involved 
introgressive hybridization". The name Scirpus lacustris subsp. flevensis D. Bakker is thus strictly applicable to a stable hybrid population occurring in the shallow water of the coastal area of the IJsselmeer between the Ketel (mouth of the IJssel) and the Ganzendiep (Bakker, 1954).

In his circumscription of Scirpus lacustris subsp. flevensis, Bakker (1954) provided a detailed description of the distinguishing characters which are summarised in Table 2. However, he recognised a total of four varieties within his concept of Scirpus lacustris subsp. lacustris (= Schoenoplectus lacustris), of which his var. glaucopsis, distinguished by its glaucous stem, is also likely to represent intermediate populations. He also recognised one variety and two forms within his concept of Scirpus lacustris subsp. glaucus (= Schoenoplectus tabernaemontani) of which his fo. maior, with larger stems ( $<2.75 \mathrm{~m}$ high and $<6 \mathrm{~cm}$ diameter) which are glaucous or "nearly green" are also likely to represent intermediates (Lousley, 1931).

It seems clear that the Scirpus lacustris subsp. flevensis of Bakker (1954) represents one element of variation within hybrids between Schoenoplectus lacustris and $S$. tabernaemontani, although "The situation is, in all probability, greatly complicated by numerous back-crosses with the parents" (Lousley, 1931). We have retained the epithet "flevensis" in the binomial for the hybrid combination.

Other authors have provided descriptions of intermediate populations as follows: Buchenau (1877): Hollerdeich, near Kattrepel, Germany. Stem grass-green; glumes reddish-brown, not asperous; stigmas 3; fruit poorly developed, intermediate between the parents.

Focke (1881): Bremen, Germany. Poorly fertile, intermediate.

Bakker (1954) (Scirpus lacustris subsp. lacustris var. glaucopsis): Zwarte Water and pool along Overijsselse Vecht near Dalfsen, Netherlands. Stems glaucous.

Bakker (1954) (Scirpus lacustris subsp. glaucus fo. maior). Brackish tidal estuaries in the south-west and the Yssellake, Netherlands. Stems glaucous, less often green; $\leq 2.75 \mathrm{~m}$ high, $6 \mathrm{~cm}$ diameter; inflorescence large and much branched.

Bakker (1954). Koelood, Oude Mass and Kamperisland, Netherlands. Leaf blades rather long; leaf-sheaths frayed; highly fertile; spikelets elongate; stigmas 3; glumes glabrous or nearly so; anthers with long-bearded connectiva.

Lousley (1931). R. Medway near Newhythe, United Kingdom. Stems $1.32 \mathrm{~m}$ high, very stout; panicle spreading; glumes asperous; stigmas 3 ; anther connectiva not bearded; achenes slightly trigonous.

Lousley (1931). G.C. Druce - Wytham ditches, Berkshire, United Kingdom. Stem glaucous; achene "more compressed than in typical lacustris"; stigmas 3.

Davis (1968). Istanbul, Turkey. Intermediate between parents but fully fertile "as shown by large amount of fruit set".

(A. Leslie pers. comm. 2020) P. Sell - Old chalk pit, Barrington, Cambridgeshire, United Kingdom. Stem glaucous but with glumes like $S$. lacustris.

(A. Leslie pers. comm. 2020). The new country park, beside Addenbrooke's Hospital, Cambridge, United Kingdom. Stems tall to at least $5 \mathrm{ft}(1.5 \mathrm{~m})$, at least $15 \mathrm{~mm}$ diameter; stigmas 2; glumes papillate. 


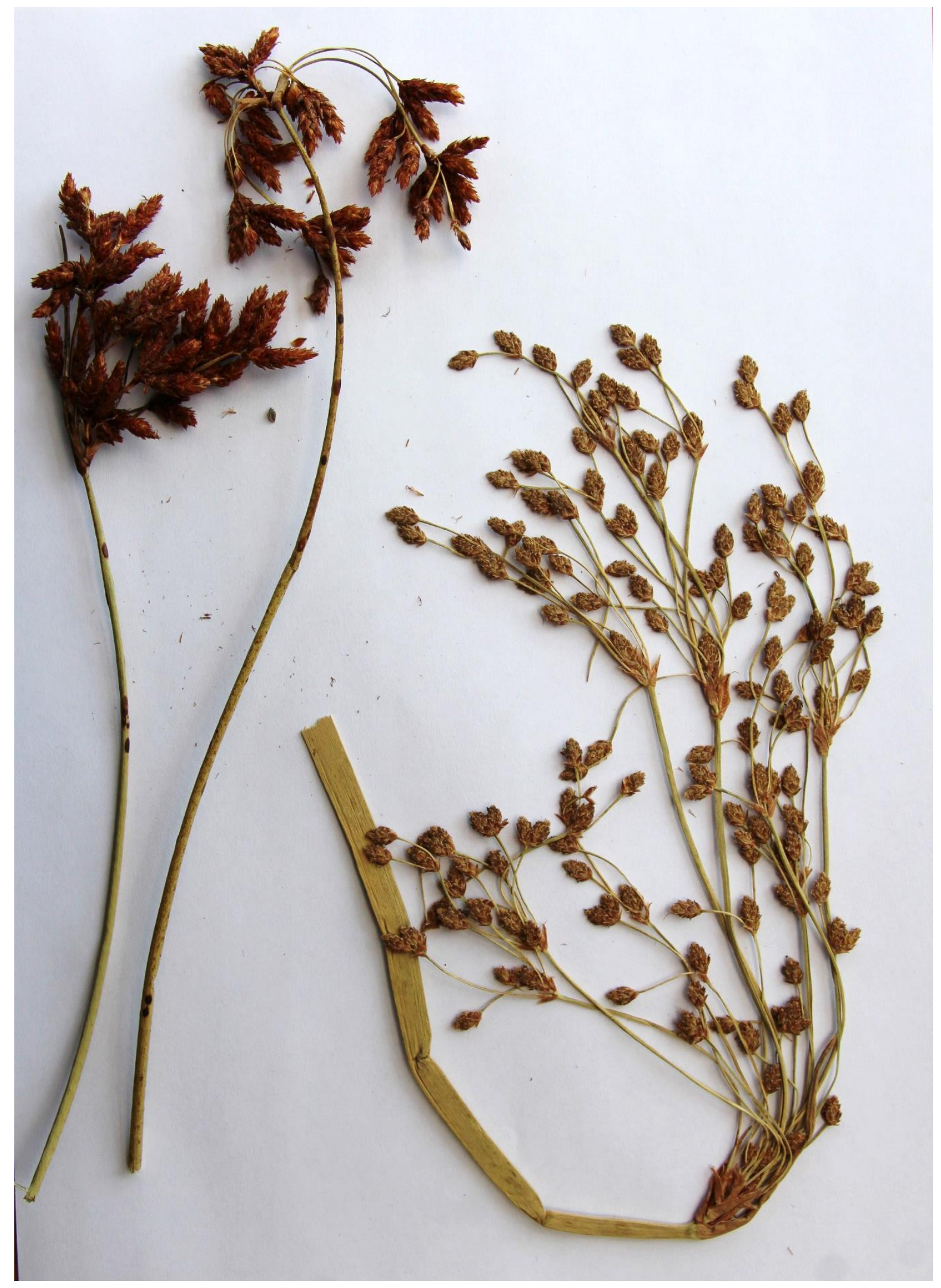

Figure 6. Inflorescences of (left) S. $x$ flevensis and (right) S. hippolyti 
Table 2. Characters given by Bakker (1954) to distinguish between his three subspecies of Schoenoplectus lacustris

\begin{tabular}{|c|c|c|c|c|}
\hline & & subsp. lacustris & subsp. flevensis & subsp. glaucus \\
\hline \multirow{4}{*}{ Rhizome } & texture & hard & fairly hard & weak \\
\hline & strength & brittle & tough & tough \\
\hline & colour & $\begin{array}{l}\text { red- or dark red- } \\
\text { brown }\end{array}$ & $\begin{array}{l}\text { yellow- or red- } \\
\text { brown }\end{array}$ & $\begin{array}{l}\text { yellow or yellow- } \\
\text { brown }\end{array}$ \\
\hline & cells & small & intermediate & large \\
\hline \multirow{3}{*}{ Stem } & dimensions & $\begin{array}{l}0.75-3.5 \mathrm{~m} \text { high; } \\
0.75-4 \mathrm{~cm} \\
\text { diameter }\end{array}$ & $\begin{array}{l}0.75-1.5 \mathrm{~m} \text { high; } \\
0.75-1.5 \mathrm{~cm} \\
\text { diameter }\end{array}$ & $\begin{array}{l}0.5-2-75 \mathrm{~m} \text { high; } \\
0.5-6 \mathrm{~cm} \\
\text { diameter }\end{array}$ \\
\hline & colour & $\begin{array}{l}\text { yellow- or dark- } \\
\text { green or glaucous }\end{array}$ & glaucous & glaucous \\
\hline & base & not club-shaped & not club-shaped & $\begin{array}{l}\text { robust plants } \\
\text { club-shaped }\end{array}$ \\
\hline \multicolumn{2}{|c|}{ Dried flowering stems } & yellow-green & yellow-green & yellow \\
\hline \multicolumn{2}{|l|}{ Leaves } & $\begin{array}{l}\text { 2-12; apices } \\
\text { frayed }\end{array}$ & 1-2; apices frayed & $\begin{array}{l}0-1 \text {; apices entire } \\
\text { or slightly frayed }\end{array}$ \\
\hline \multicolumn{2}{|l|}{ Spikelets } & $\begin{array}{l}\text { elongate or } \\
\text { elongate-ovoid }\end{array}$ & $\begin{array}{l}\text { elongate or } \\
\text { elongate-ovoid }\end{array}$ & $\begin{array}{l}\text { ovoid, elongate or } \\
\text { elongate-ovoid }\end{array}$ \\
\hline \multicolumn{2}{|l|}{ Glumes } & $\begin{array}{l}\text { glabrous or midrib } \\
\text { not asperous; } \\
\text { usually brown }\end{array}$ & $\begin{array}{l}\text { asperous on the } \\
\text { midrib, outer } \\
\text { glumes also near } \\
\text { the midrib; brown }\end{array}$ & $\begin{array}{l}\text { all outer glumes } \\
\text { asperous; red- } \\
\text { brown }\end{array}$ \\
\hline \multicolumn{2}{|c|}{ Number of stigmas } & 3 & $\begin{array}{l}2-3(60: 40 \% \text { in } \\
\text { each spikelet, } 3 \\
\text { stigmas more } \\
\text { frequent at apex) }\end{array}$ & $2-3$ \\
\hline \multicolumn{2}{|c|}{$\begin{array}{l}\text { Anther connective } \\
\text { (apices) }\end{array}$} & bearded & $\begin{array}{l}\text { bearded (shorter } \\
\text { than lacustris) }\end{array}$ & $\begin{array}{l}\text { very shortly } \\
\text { bearded }\end{array}$ \\
\hline \multirow{2}{*}{ Achenes } & $\begin{array}{l}\text { cross- } \\
\text { section }\end{array}$ & bluntly trigonous & $\begin{array}{l}\text { faintly trigonous } \\
\text { or compressed }\end{array}$ & compressed \\
\hline & $\begin{array}{l}\text { length (exc. } \\
\text { beak) }\end{array}$ & $2.5-3 \mathrm{~mm}$ & about $2.5 \mathrm{~mm}$ & about $2.5 \mathrm{~mm}$ \\
\hline
\end{tabular}

All of these records are likely to involve hybrids between $S$. lacustris and $S$. tabernaemontani. It therefore seems likely that at the interface between coastal saline waters with freshwater habitats within the range of the parents, there is a good chance of populations of $S . \times$ flevensis occurring, as well as inland wherever $S$. tabernaemontani occurs. There is increasing potential for hybridisation between $S$. lacustris and $S$. tabernaemontani as both parent species are being planted outside their natural ranges and habitats. As a consequence, they are being increasingly brought into sympatry. 


\section{Acknowledgements}

We are extremely grateful to Alexander Bobrov, Isabel Larridon, Alan Leslie and Owen Mountford for help with background information and to Steve Russell for performing the molecular studies. We would also like to thank John Bruinsma, Klaus van de Weyer and Gerhard Wiegleb for information and comments provided in response to a previous version of this ms and Attila Mesterhazy for access to his specimen of $S$. hippolyti. Funding for all of the genetic analysis, which also enabled collection of data on $S$. $\times$ flevensis came from the Natural England Species Recovery programme, under projects managed by John Martin and Ian Taylor to whom we are extremely grateful.

\section{References}

Bakker, D. 1954. Miscellaneous notes on Scirpus lacustris L. sensu lat. in the Netherlands. Acta Botanica Neerlandica, 3(4): 425-445.

Brügger, C.G. 1882. Botanische Mitteilungen. Jahresbericht der Naturforschenden Gesellschaft Graubündens, 25, 54-112.

Buchenau, F. 1877. Flora von Bremen: zum Gebrauch in Schulen und auf Excursionen. Bremen: C. Ed. Müller.

Davis, P.H, 1968. Flora of Turkey and the East Aegean Islands. Vol. II. Edinburgh: Edinburgh University.

Easy, G. 1990. A note on Cambridgeshire bulrushes. Nature in Cambridgeshire, 32: 58.

Focke, W.O. 1881. Die Pflanzen-mischlinge: Ein beitrag zur biologie der gewächse. Berlin: Gebrüder Borntrager.

Grenier \& Godron 1855-56. Flore de France ou description des plantes qui croissent naturellement en France et en Corse. Paris: J.B. Baillière.

Jermy, A.C., Simpson, D.A., Foley, M.J.Y. \& Porter, M.S. 2007. Sedges of the British Isles. BSBI Handbook No $1,3^{\text {rd }}$ ed. London: Botanical Society of the British Isles.

Kukkonen, I. 1996. Notes on the treatment of Cyperaceae for Flora Iranica. Annalen des Naturhistorischen Museums in Wien. Serie B für Botanik und Zoologie 98: Bd., Suppl. Festschrift 90 Jahre Karl Heinz Rechinger: 87-95.

Lansdown, R.V. 2010. Donington to Surfleet Link: Macrophyte survey report. Halcrow-Jacobs Alliance. Peterborough: Unpublished report to the Environment Agency.

Lansdown, R.V. 2017. Review of molecular studies of club-rush samples in relation to conservation of triangular club-rush (Schoenoplectus triqueter). Peterborough: Unpublished report to Natural England.

Lousley, J. E. 1931. The Schoenoplectus group of the genus Scirpus in Britain. Journal of Botany, 69: 151-163.

Dai, L-K., Liang, S-Y., Zhang, S., Tang, Y., Koyama, T., Tucker, G.C., Simpson, D.A., Noltie, H.J., Strong, M.T., Bruhl, J.J., Wilson, K.L. \& Muasya, A.M. 2010. 22 Cyperaceae. In: Wu, Z.Y., Raven, P.H. \& Hong, D.Y., (eds.) Flora of China Volume 23. Acoraceae-Zosteraceae. Beijing: Science Press and St. Louis: Missouri Botanical Garden Press.

Otzen, D. 1962. Chromosome studies in the genus Scirpus L., Section Schoenoplectus Benth. et Hook., in the Netherlands. Acta Botanica Neerlandica 11: $37-46$. 
Pignotti L. 2003. Scirpus L. and related genera (Cyperaceae) in Italy. Webbia, 58(2): 281-400.

Rose, F. 1989. Colour identification guide to the grasses, sedges, rushes and ferns of the British Isles and north-western Europe. London: Viking.

Saubin, M., Gargiulo, R. \& Fay, M.F. 2018. Evaluation of hybridisation between Schoenoplectus species (Cyperaceae) on English riversides. Peterborough: Unpublished Report to Natural England,

Sell, P. \& Murrell, G. 1996. Flora of Great Britain and Ireland. Vol. 5. ButomaceaeOrchidaceae. Cambridge: Cambridge University Press.

Stace, C.A. 2019. New flora of the British Isles. $4^{\text {th }}$ ed. Middlewood Green, Suffolk: C\&M Floristics.

Copyright retained by author(s). Published by BSBI under the terms of the Creative Commons Attribution 4.0 International Public License.

ISSN: $2632-4970$

https://doi.org/10.33928/bib.2020.02.190 